\title{
Hubungan Personal Hygiene Dan Penggunaan Kontrasepsi dengan Kejadian Keputihan Pada Wanita Usia Subur (WUS)
}

\author{
The Relationship Of Personal Hygiene dnd Use of Contraception With The Even of White In \\ Women's Farming Women
}

\author{
Yeni Riza *1, Nurul Indah Qariati ${ }^{2}$, Asrinawaty ${ }^{3}$ \\ ${ }_{1,2,3}$ Fakultas Kesehatan Masyarakat Universitas Islam Kalimantan MAB Banjarmasin \\ Email Korespondensi : yeniriza86@gmail.com
}

\begin{abstract}
Abstrak
Jumlah Wanita Usia Subur (WUS) di Kelurahan Tanjung Pagar yang berkisar umur 15-49 tahun yang sudah menikah tergolong banyak dan sering memanfaatkan sungai untuk mandi, cuci, dan kakus (MCK) walaupun air sungai sudah tidak layak pakai. Penelitian ini bertujuan untuk mengetahui hubungan Personal Hygiene dan Penggunaan Kontrasepsi dengan kejadian keputihan pada Wanita Usia Subur (WUS) di Kelurahan Tanjung Pagar Banjarmasin. Metode penelitian yang digunakan adalah survey analitik dengan pendekatan Cross Sectional. Populasi dalam penelitian ini adalah Wanita Usia Subur (WUS) di Kelurahan Tanjung Pagar dengan sampel 97 orang. Data analisis dengan uji chi-square. Teknik pengambilan sampel Purposive Sampling. Instrumen yang digunakan dalam penelitian ini adalah kuesioner. Hasil penelitian menunjukan 57,7\% mengalami keputihan tidak normal, 76,3\% memiliki Personal Hygiene yang kurang baik dan 80,4\% memakai kontrasepsi hormonal. Hasil analisis bivariat menunjukan bahwa ada hubungan antara Personal Hygiene dengan kejadian keputihan $(\mathrm{p}=0,000)$, dan tidak ada antara hubungan penggunaan kontrasepsi dengan kejadian keputihan $(\mathrm{p}=0,808)$. Untuk puskesmas dapat memberikan informasi lebih lanjut tentang keputihan melalui penyuluhan kepada warga sekitar mengenai Personal Hygiene khususnya cara menjaga kebersihan organ kewanitaan dengan baik.
\end{abstract}

Kata Kunci : Personal hygiene, kontrasepsi, keputihan

\begin{abstract}
The number of women of infertile age (WUS) in Tanjung Pagar sub-district, which is about 15-49 years old who are married, are many and often use river for bathing, washing and toilet (MCK) although river water is not suitable for use. This study aims to determine the relationship between Personal Hygiene and Contraceptive Use with the incidence of leucorrhea in Women Aged Fertile (WUS) in Tanjung Pagar Banjarmasin village. The research method used is analytical survey with Cross Sectional approach. The population in this study is Women Age Fertile (WUS) in Tanjung Pagar Village with sample 97 people. Data analysis with chi-square test. Purposive Sampling Technique. Instrument used in this research is questionnaire. The results showed $57.7 \%$ experienced abnormal vaginal discharge, $76.3 \%$ had poor Personal Hygiene and $80.4 \%$ were taking hormonal contraceptives. The result of bivariate analysis showed that there was a correlation between Personal Hygiene and whiteness ( $p$ $=0,000)$, and there was no relationship between contraceptive use and whiteness $(p=0,808)$. For health centers can provide more information about vaginal discharge through counseling to local people about Personal Hygiene especially how to maintain the cleanliness of the female organs properly.
\end{abstract}

Keywords: Personal hygiene, contraception, vaginal discharge 


\section{PENDAHULUAN}

Kesehatan reproduksi merupakan kesehatan secara fisik, mental, dan kesejahteraan sosial secara utuh pada semua hal yang berhubungan dengan sistem dan fungsi, serta proses reproduksi dan bukan hanya kondisi yang bebas dari penyakit atau kecacatan [1]. Menjaga kesehatan berawal dari menjaga kebersihan. Hal ini juga berlaku bagi kesehatan organ seksual, termasuk vagina. Vagina merupakan salah satu organ reproduksi wanita yang sangat rentan terkena penyakit infeksi, salah satunya adalah keputihan [2]. Masalah keputihan adalah masalah yang sejak lama menjadi persoalan bagi kaum wanita. Wanita menunjukkan 75\% wanita di dunia pasti menderita keputihan, paling tidak sekali seumur hidup dan 45\% diantaranya dapat mengalami dua kali atau lebih. Keputihan dapat disebabkan karena penggunaan alat kontrasepsi dalam pemakaian kontrasepsi, keputihan meningkat $50 \%$ dibandingkan dengan wanita yang tidak memakai kontrasepsi [3].

Tanda keputihan normal atau keputihan fisiologis adalah cairan sekresi berwarna bening, tidak lengket dan encer, tidak mengeluarkan bau yang menyengat, gejala ini merupakan proses normal sebelum atau sesudah haid dan tanda masa subur pada wanita tertentu, pada bayi perempuan yang baru lahir, dalam waktu satu hingga sepuluh hari, dari vaginanya dapat keluar cairan akibat pengaruh hormon yang dihasilkan oleh plasenta atau urin, gadis muda kadang-kadang juga mengalami keputihan sesaat sebelum masa pubertas, biasanya gejala ini akan hilang dengan sendirinya, biasanya keputihan yang normal tidak disertai dengan rasa gatal. Tanda keputihan tidak normal atau patologis adalah keluarnya cairan berwarna putih pekat, putih kekuningan, putih kehijauan atau putih kelabu dari saluran vagina, cairan ini dapat encer atau kental, lengket dan kadang-kadang berbusa, cairan ini mengeluarkan bau yang menyengat, pada penderita tertentu, terdapat rasa gatal yang menyertainya serta dapat mengakibatkan iritasi pada vagina, terkadang sakit saat buang air kecil [4].

Personal hygiene adalah suatu tindakan untuk memelihara kebersihan dan kesehatan seseorang untuk kesejahteraan fisik dan psikis, kurang perawatan diri adalah kondisi dimana seseorang tidak mampu melakukan perawatan kebersihan untuk dirinya [5]. Seperti layaknya organ tubuh yang lain, organ reproduksi seksual juga harus diberi perawatan dengan baik. berikut yang bisa dilakukan yaitu usahakan vagina senantiasa kering dan tidak lembab, karena keadaan basah memudahkan berjangkitnya infeksi dari luar, selalu mencuci tangan sebelum menyentuh vagina, mandi dengan teratur dengan membasuh vagina dengan air hangat dan sabun yang lembut, praktekkan cara menyeka yang benar yaitu dari arah depan ke belakang, hindari penggunaan handuk milik orang lain untuk mengeringkan vagina kita, selalu gunakan celana dalam yang bersih dan terbuat dari bahan katun, jangan menggunakan alat pembersih kimiawi tertentu karena akan merusak keasaman vagina yang berfungsi menumbuhkan bakteri atau kuman yang masuk. demikian juga tidak diperbolehkan menggunakan deodorant atau spray, cairan pembasuh (douches), sabun yang keras, serta tisu yang berwarna dan berparfum, perawatan sistem reproduksi dengan mencukur sebagian dari rambut kemaluan secara teratur, jangan menggunakan alat-alat bantuan untuk masturbasi, karena hal ini bisa menyebabkan robeknya selaput dara dan infeksi pada vagina [6].

Kontrasepsi adalah menghindari/mencegah terjadinya kehamilan sebagai akibat pertemuan antara sel telur yang matang dengan sel sperma tersebut [7]. Metode kontrasepsi terdapat dengan dua cara yaitu dengan alat dan tanpa alat/alamiah, metode dengan alat terbagi menjadi dua menurut cara kerjanya yaitu hormonal dan nonhormonal. Kontrasepsi hormonal menggunakan alat seperti pil, suntik dan implan, IUD/IUS. Kontrasepsi nonhormonal menggunakan alat seperti metode MOW, MOP, IUD nonhormonal, dan kondom. Sedangkan metode tanpa alat/ alamiah seperti MAL (Metode Amenore Laktasi), senggama terputus, suhu basal, metode lendir serviks, dan kalender/pantang berkala [8]. 
Berdasarkan survei pendahuluan yang telah dilakukan peneliti pada tanggal 18 April 2018 bahwa Kelurahan Tanjung Pagar dilalui oleh Sungai Kelayan yang memiliki pola aliran sungai yang pasang surut dan merupakan salah satu kategori sungai kecil di Kota Banjarmasin. Pemukiman penduduk di Kelurahan Tanjung Pagar berupa rumah panggung yang badan rumahnya mengambil ruang sungai sehingga badan sungai semakin sempit dan keadaan bangunan terlihat tidak ada ruang terbuka karena letak bangunan yang sangat rapat. Menurut informasi yang didapat peneliti dari Kelurahan Tanjung Pagar bahwa jumlah Wanita Usia Subur (WUS) berkisar umur 15-49 tahun yang sudah menikah tergolong banyak dan sering memanfaatkan sungai untuk mandi, cuci, dan kakus (MCK) walaupun secara fisik dan fisiologis air sungai sudah tidak layak pakai. Air PDAM memang sudah disediakan oleh pemerintah namun sering terjadi ketidaklancaran air tersebut masuk ke Kelurahan Tanjung Pagar sehingga air PDAM hanya dipakai untuk minum ataupun memasak saja.

Berdasarkan latar belakang tersebut peneliti merasa tertarik untuk melakukan penelitian mengenai "Hubungan Personal Hygiene dan Penggunaan Kontrasepsi Dengan Kejadian Keputihan Pada Wanita Usia Subur (WUS) Di Kelurahan Tanjung Pagar Banjarmasin”.

\section{METODE}

Penelitian ini menggunakan metode survey analitik dengan pendekatan Cross Sectional. Dari populasi sebanyak 2726 orang dihitung dengan menggunakan rumus slovin sehingga hasil sampel sebanyak 97 responden, Pengambilan sampel dalam penelitian ini menggunakan metode Non Random Sampling dengan teknik Purposive Sampling yang artinya pengambilan sampel purposive didasarkan pada pertimbangan tertentu yang dibuat oleh peneliti sendiri berdasarkan kriteria inklusi yaitu wanita Usia Subur (WUS) yaitu wanita yang menikah dan tidak menopause, wanita yang bertempat tinggal dipemukiman padat, wanita yang menggunakan kontrasepsi, maupun itu kontrasepsi hormonal, nonhormonal, dan tanpa alat/alamiah, bersedia menjadi responden dan kriteria eksklusi yaitu wanita yang berusia $<15$ tahun dan menopause, tidak bisa membaca dan menulis. Instrumen dalam penelitian ini menggunakan Kuesioner yang dimodifikasi dan diadopsi dari Simanjuntak (2015), Pambudi (2014) dan Zahara (2014) yang sudah melakukan uji validitas dan reabilitas. Untuk mengetahui hubungan dari masing-masing variabel independen dengan variabel dependen dalam penelitian ini menggunakan uji chi-square pada taraf kepercayaan $95 \%$. Kriteria hubungan variabel ditentukan oleh nilai $\mathrm{p}$ value. Apabila $\leq \alpha 0,05$, maka $\mathrm{H}_{0}$ ditolak dan $\mathrm{H}_{\mathrm{a}}$ diterima berarti ada hubungan antara variabel independen dengan variabel dependen. Apabila nilai $\mathrm{p}>\alpha 0,05$, maka $\mathrm{H}_{0}$ diterima dan $\mathrm{H}_{\mathrm{a}}$ ditolak berarti tidak ada hubungan antara variabel independen dan variabel dependen.

\section{HASIL DAN PEMBAHASAN}

\section{Kejadian Keputihan}

Jumlah responden yang mengalami jenis keputihan tidak normal pada penelitian ini dikatakan lebih banyak dibandingkan dengan jumlah responden yang mengalami jenis keputihan normal. Responden yang mengalami keputihan tidak normal paling banyak mengeluhkan gatal pada vagina serta cairan keputihan berwarna putih pekat, putih kekuningan, putih kehijauan dan berbau menyengat. Sebelum keputihan tersebut berubah warna menjadi pekat dan berbau, responden menyatakan mengalami keputihan normal dalam waktu yang lama.

Hal ini dapat terjadi dikarenakan tidak menjaga kebersihan vagina dengan baik, menggunakan jamban yang kotor sehingga untuk membasuh organ intim menggunakan air sungai, menggunakan pakaian dalam yang sangat ketat, melakukan cara pembilasan vagina dengan arah yang salah, umumnya melakukan dari arah anus ke arah vagina, yang benar adalah dari vagina ke arah anus, melakukan pertukaran pemakaian handuk dengan orang lain, men- 
galami stress dan kelelahan, tidak sering mengganti pembalut saat menstruasi, sering menggaruk - garuk pada daerah organ intim, tinggal dilingkungan yang kotor, dan memakai pantyliner yang tidak berkualitas atau terbuat dari bahan daur ulang dan mengandung pemutih.

\section{Personal Hygiene}

Jumlah responden yang memiliki Personal Hygiene yang kurang baik dapat dikatakan lebih banyak dibandingkan dengan jumlah responden yang memiliki Personal Hygiene yang baik. Hal itu dikarenakan kebanyakan responden kurang tahu cara pemeliharaan organ reproduksi sehingga dalam hal penerapan yang baik masih kurang. rata-rata responden dengan Personal Hygiene yang kurang baik menjawab tidak mengganti pembalut satu kali dalam 4 jam sebanyak 74 responden karena menurut responden mengganti pembalut 4 jam sekali terlalu sering jika dirasa darah haid belum banyak apalagi ada beberapa responden yang berdagang dipasar sehingga tidak ada waktu dan malas harus ke jamban untuk mengganti pembalut, yang menggunakan air tergenang di ember saat membasuh vagina sebanyak 72 responden (97,3\%) karena air PDAM tidak lancar sehingga responden harus menyimpan air bersih di ember atau penampungan air lainnya, yang menggunakan air sungai untuk mandi sebanyak 59 responden (79,7\%) karena masih ada responden yang tidak bisa memasang air PDAM maka untuk menghemat membeli air bersih responden melakukan aktivitas mandi disungai, yang kontak langsung dengan air sungai lebih dari 3 kali sebanyak 54 responden (73\%) dan yang menggunakan air sungai untuk mencuci celana dalam sebanyak 54 responden (73\%) karena memang kebiasaan responden menggunakan air sungai tidak bisa di ubah sehingga menggunakan air bersih hanya untuk memasak dan minum dan yang menggunakan celana ketat sebanyak 44 responden (59\%) karena responden beralasan memakai celana ketat terasa nyaman dan bisa mengikuti tren.

\section{Penggunaan Kontrasepsi}

Jumlah responden yang menggunakan jenis kontrasepsi hormonal yaitu pil dan suntik tergolong lebih banyak dibandingkan dengan jumlah responden yang menggunakan jenis kontrasepsi nonhormonal dan tanpa alat/alamiah. Hal ini dikarenakan pengetahuan responden tentang berbagai alat kontrasepsi masih kurang karena dilihat dari karakteritik umum responden berdasarkan pendidikan bahwa responden kebanyakan hanya menyelesaikan pendidikan menengah saja bahkan ada yang tidak bersekolah. Jika dilihat berdasarkan umur, responden yang masuk periode reproduksi sehat (20-35 tahun) tergolong banyak sehingga responden memilih pil atau suntik karena beranggapan akan lebih cepat hamil jika berhenti memakai kontrasepsi tersebut dan melakukan hubungan seksual. Adapun faktor pengaruh lingkungan sekitar yaitu rata-rata responden cenderung mengikuti teman yang memakai pil dan suntik, responden takut untuk memakai jenis kontrasepsi lain dengan alasan takut tidak cocok.

\section{Hubungan Personal Hygiene Dengan Kejadian Keputihan}

Berdasarkan hasil penelitian menunjukkan bahwa ada hubungan antara Personal Hygiene dengan kejadian keputihan pada Wanita Usia Subur (WUS) di Kelurahan Tanjung Pagar Banjarmasin. Hal ini didasarkan pada uji chisquare yang diperoleh $p$-value $0,000(\mathrm{p}<0,05)$. Hasil penelitian ini sejalan dengan penelitian Ramayanti (2017) yang menyatakan bahwa ada hubungan antara Personal Hygiene dengan kejadian keputihan pada remaja putri SMA Muhammadiyah 5 Yogyakarta. Berdasarkan hasil penelitian ini didapatkan bahwa responden yang memiliki Personal Hygiene yang kurang baik adalah 74 responden, 54 responden (73\%) diantaranya mengalami keputihan tidak normal. Hal itu terjadi karena responden kebanyakan malas mengganti celana dalam jika sudah lembab, mandi 
dan mencuci pakaian serta celana dalam disungai bersama karena responden merasa itu adalah hiburan tersendiri.

Responden yang memiliki Personal Hygiene yang kurang baik terdapat 74 responden, 20 responden (27\%) diantaranya mengalami keputihan normal. Hal ini terjadi karena sistem kekebalan tubuhnya baik terhadap suatu penyakit sehingga tidak mudah terserang kuman, bakteri dan jamur penyebab keputihan tidak normal.

Berdasarkan hasil penelitian didapatkan bahwa responden yang memiliki Personal Hygiene yang baik sebanyak 23 responden, 21 responden $(91,3 \%)$ diantaranya mengalami jenis keputihan normal. Hal ini tentu saja karena responden sudah terbiasa menerapkan kebiasaan-kebiasaan yang sehat untuk merawat organ kewanitaannya seperti membasuh daerah kewanitaan dengan air bersih, menggunakan sabun yang lembut untuk membersihkan area vagina, membasuh daerah kewanitaan dari depan ke belakang saat buang air kecil/air besar, dan mencukur bulu kemaluan di area vagina untuk menghindari timbulnya vagina.

Responden yang memiliki Personal Hygiene yang baik sebanyak 23 responden, 2 responden (8,7\%) diantaranya mengalami jenis keputihan tidak normal. Hal ini terjadi dikarenakan responden mengalami stress dan kelelahan, tinggal di lingkungan yang kotor seperti menggunakan wc yang kotor, dan adapun faktor kebersihan suami, jika suami tidak menjaga kebersihan organ intim minimal sebelum melakukan hubungan seksual maka akan berdampak pada wanita salah satunya mengalami keputihan.

\section{Hubungan Penggunaan Kontrasepsi Dengan Kejadian Keputihan}

Dari hasil penelitian menunjukkan bahwa tidak ada hubungan antara penggunaan kontrasepsi dengan kejadian keputihan pada Wanita Usia Subur (WUS) di Kelurahan Tanjung Pagar Banjarmasin. Hal ini didasarkan pada hasil uji chi-square yang diperoleh $p$-value $0,808(\mathrm{p}>0,05)$. Hasil penelitian ini tidak sejalan dengan penelitian Yulianti (2017) yang menyatakan bahwa $p$-value $0,001(\mathrm{p}<0,05)$ artinya ada hubungan penggunaan kontrasepsi hormonal (oral) dengan kejadian flour albus. Hal ini dikarenakan tempat dan sasaran penelitian yang berbeda. Pada penelitian ini dilakukan tahun 2018 di Dusun Pungging Krisik Desa Balongmasin Kecamatan Pungging Kabupaten Mojokerto dan sasaran penelitiannya hanya kepada wanita yang memakai kontrasepsi oral atau pil KB, sedangkan pada penelitian ini dilakukan di Kelurahan Tanjung Pagar Banjarmasin dan sasarannya adalah Wanita Usia Subur (WUS) yang memakai salah satu dari 3 kategori penggunaan kontrasepsi yaitu hormonal, nonhormonal dan tanpa alat/alamiah.

Berdasarkan hasil penelitian didapatkan bahwa responden yang memakai jenis kontrasepsi hormonal sebanyak 78 responden, 32 responden $(41,6 \%)$ yang mengalami keputihan normal. Hal ini tentu saja dikarenakan pada umumnya wanita mengalami keputihan pada saat sebelum atau sesudah menstruasi, dan pada saat terangsang sebelum melakukan hubungan seksual. Adapun 46 responden (59\%) yang memakai jenis kontrasepsi hormonal yang mengalami keputihan tidak normal. Hal itu dikarenakan responden tidak menjaga kebersihan organ kewanitaan dengan baik dan responden kurang mengetahui bahwa timbulnya ciri-ciri keputihan tidak normal adalah tanda bahwa kontrasepsi yang dipakai tidak cocok.

Menurut Angelina (2013) didalam penelitian Lestari (2013), efek samping kontrasepsi hormonal diantaranya mual, kenaikan berat badan, sakit kepala, dan keputihan yaitu jenis keputihan fisiologis (flour albus fisiologis). Hasil penelitian Lestari (2013) terdapat hasil $X^{2}$ hitung $(5,595) \geq X^{2}$ tabel $(2,349)$ artinya ada hubungan yang signifikan antara pemakaian kontrasepsi hormonal kombinasi dengan kejadian flour albus fisiologi (keputihan normal), sama maknanya dengan penelitian ini bahwa penggunaan kontrasepsi hormonal tidak ada hubungan dengan penyebab keputihan tidak normal karena terjadinya flour albus fisiologi pada akseptor hormonal kombinasi dikarenakan bergesernya flora normal vagina akibat dari perubahan hormon di dalam tubuh. Sebagian akseptor mengalami 
keputihan tidak normal karena tidak diiringi dengan perilaku sehat seperti personal hygiene dengan tidak memakai sabun pembersih vagina dan mengganti celana dalam lebih dari 2x setiap hari [9]-[13]. .

\section{KESIMPULAN DAN SARAN}

Penelitian ini menyimpulkan bahwa bahwa kejadian kasus DBD di Kota Banjarmasin dalam rentang tahun 2012-2106 terjadi fluktuatif, kejadian DBD lebih banyak terjadi pada laki-laki (147 orang) dibandingkan dengan perempuan (98 orang), serta korelasi kepadatan penduduk terhadap kejadian DBD. Secara umum tidak terdapat korelasi antara kepadatan penduduk diseluruh wilayah kecamatan di Kota Banjarmasin. Olehnya itu diharapkan perhatian penuh dari pemerintah tentang kejadian DBD. Penelitian merekomendasikan perlu meningkatkan kebersihan organ kewanitaan seperti menggunakan sabun yang lembut untuk membersihkan area vagina, mencukur bulu kemaluan agar terhindar dari kuman, jamur dan bakteri penyebab keputihan, mengganti pembalut 4 jam sekali, mengganti celana dalam jika sudah lembab, selalu membersihkan vagina dengan air bersih, memilih kontrasepsi yang baik dan hindari organ kewanitaan kontak langsung dengan air sungai. Bagi peneliti selanjutnya diharapkan melakukan penelitian lanjutan di wilayah yag berbeda dengan penambahan variabel lain yang diduga berhubungan dengan kejadian keputihan seperti sanitasi lingkungan, kebersihan suami, dan peran petugas kesehatan.

\section{DAFTAR PUSTAKA}

[1] BKKBN, "Rencana Strategis Badan Kependudukan Dan Keluarga Berencana Nasional,” Bkkbn, 2015.

[2] E. Rahmawati, "GAMBARAN KESEHATAN REPRODUKSI PENYAPU JALANAN PEREMPUAN DI KOTA BALIKPAPAN TAHUN 2016,” Mahakam Midwifery J., vol. 2, no. 1, pp. 7-22, 2017.

[3] G. A. Marhaeni, "Keputihan pada Wanita,” J. Skala Husada J. Heal., 2017.

[4] A. Herawati, D. Mahdiyah, and H. Khatimah, "HUBUNGAN PEKERJAAN DAN VULVA HYGIENE DENGAN KEJADIAN KEPUTIHAN PADA IBU HAMIL DI PUSKESMAS SUNGAI BILU BANJARMASIN," Din. Kesehat. J. KEBIDANAN DAN KEPERAWATAN, 2016.

[5] F. H. Ismail, C. T. Chik, R. Muhammad, and N. M. Yusoff, "Food Safety Knowledge and Personal Hygiene Practices amongst Mobile Food Handlers in Shah Alam, Selangor," Procedia - Soc. Behav. Sci., 2016.

[6] S. A. Putri and E. P. Saputra, "Perancangan Aplikasi Sistem Pakar Diagnosa Awal Kanker Reproduksi Wanita Dengan Metode Certainty Factor," J. MEDIA Inform. BUDIDARMA, vol. 2, no. 3, 2018.

[7] D. Trisnawarman and W. Erlysa, "Sistem Penunjang Keputusan Pemilihan Metode / Alat Kontrasepsi," Gematika J. Manaj. Inform., 2007.

[8] A. P. K. Marikar, R. Kundre, and Y. Bataha, "Faktor-Faktor Yang Berhubungan Dengan Minat Ibu Terhadap Penggunaan Alat Kontrasepsi Dalam Rahim (AKDR) Di Puskesmas Tumingting Kota Manado," e-Journal Keperawatan (eKp), 2015.

[9] A. Wijayanti, I. Sumiyarsi, and A. Nugraheni, "Hubungan Antara Penggunaan Jenis Pembalut Saat Menstruasi Dengan Kejadian Keputihan Di SMK Negeri 1 Sukoharjo,” J. EDUMidwifery, 2017.

[10] N. Y. Triana, A. S. Fitriani, and E. Badawi, "Keluhan Keputihan Pada Akseptor Kontrasepsi Alat Kontrasepsi Dalam Rahim (Akdr),"Viva Med., 2015.

[11] dan R. W. Zannah, Intan Riyadhul, Ida Maryati, "Gambaran Keluhan-Keluhan Akibat Penggunaan Alat Kontrasepsi Iud Pada Akseptor Iud Di Wilayah Kerja Puskesmas Sukajadi Kota Bandung," Students e-Journal, 2012.

[12] A. Putri Sujiwa, "Hubungan Antara Penggunaan Kontrasepsi Oral Dengan Kejadian Stroke Iskemik Di Poli Saraf Rsud Dr.Moewardi," Fak. Kedokt. Univ. Muhammadiyah Surakarta, 2014.

[13] V. Wulandari, "Hubungan Faktor Risiko Penggunaan Kontrasepsi Oral dan Aktivitas Seksual Dengan Kejadian Kanker Serviks," J. Berk. Epidemiol., 2016. 